\title{
BIOHYDROGEN PRODUCTION FROM WASTES OF PLANT AND ANIMAL ORIGIN VIA DARK FERMENTATION
}

\author{
Weronika CIECIURA-WŁOCH*, Sebastian BOROWSKI \\ Institute of Fermentation Technology and Microbiology, Lodz University of Technology, \\ Wólczańska 171/173, 90-924 Łódź, Poland
}

Received 31 January 2018; accepted 31 January 2019

\begin{abstract}
This study investigated the batch experiments on biohydrogen production from wastes of plant and animal origin. Several substrates including sugar beet pulp (SBP), sugar beet leaves (SBL), sugar beet stillage (SBS), rye stillage (RS), maize silage (MS), fruit and vegetable waste (FVW), kitchen waste (KW) and slaughterhouse waste (SHW) including intestinal wastes, meat tissue, post flotation sludge were tested for their suitability for hydrogen production. Generally, the substrates of plant origin were found to be appropriate for dark fermentation, and the highest hydrogen yield of $280 \mathrm{dm}^{3} \mathrm{H}_{2} / \mathrm{kg}$ VS was obtained from fruit and vegetable waste. Contrary to these findings, slaughterhouse waste as well as kitchen waste turned out to be unsuitable for hydrogen production although their methane potential was high. It was also concluded that the combined thermal pretreatment with substrate acidification was needed to achieve high hydrogen yields from wastes.
\end{abstract}

Keywords: biohydrogen, plant biomass, food waste, dark fermentation, anaerobic digestion.

\section{Introduction}

Consumption of fossil fuels such as brown coal or crude oil is considered to be the main reason for air pollution and unfavorable climate changes as a result of increasing concentrations of carbon dioxide, nitrogen oxide and ashes in the atmosphere (Ozkan, Erguder, \& Demirer, 2011). Moreover, coal and petroleum are finite resources and this forces the search for new, alternative energy sources. Among various alternatives, hydrogen with its high-energy yield $(122 \mathrm{~kJ} / \mathrm{g})$ plays an important role. Hydrogen is known as an environmentally friendly energy source since its combustion does not emit any carbonbased gases, which would induce the climate changes by greenhouse effect intensification (Argun \& Dao, 2017; Chu et al., 2008). Hydrogen can be generated in various strategies; in thermochemical (thermo-chemical gasification), electrochemical (water electrolysis) or biological processes. Conventional methods of hydrogen production are energy consuming, require high temperatures and need using fossil fuels (natural gas, coal) to generate power (Argun \& Dao, 2017). Contrary to them, biological hydrogen production attracts more and more attention, is less energy intensive (Ozkan et al., 2011) and can utilize wastes. Bioydrogen can be generated via several different metabolic pathways, including direct water biophotolysis by green algae, indirect water bio-photolysis by cyanobacteria, photo-fermentation by photosynthetic purple non-sulfur bacteria or dark fermentation (DF) by heterotrophic anaerobic bacteria (Escamilla-Alvarado, Rios-Leal, Ponce-Noyola, \& Poggi-Varaldo, 2012; Urbaniec \& Bakker, 2015). The latter process is of particular interest due to several advantages including production of hydrogen with no light needed, the use of various kinds of substrates and that it is one of the options for recycle the waste biomass. In dark fermentation, hydrogen is produced by a variety of anaerobic and facultative microorganism among which Clostridiaceae and Enterobacteriaceae families play a crucial role (Fang, Zhang, \& Liu, 2002). In particular, acidogenic bacteria of Clostridium sp., Enterobacter sp., Citrobacter sp., Bacilluss p. and Alcaligenes sp. could ferment mono- and disaccharides to hydrogen, carbon dioxide and organic acids (acetic acid, lactic acid, butyric acid, propionic acid) (Urbaniec \& Bakker, 2015; Ghimire et al., 2015). Clostridium and Bacillus genera are characterized by the formation of spores in response to unfavorable environmental conditions, which is of importance regarding practical applications of these bacteria for hydrogen generation (Argun \& Dao, 2017). Considering feedstock for hydrogen production, they have to meet specific criteria.

${ }^{*}$ Corresponding author. E-mail: weronika.cieciura-wloch@edu.p.lodz.pl 
A substrate should be rich mainly in carbohydrates, be received from sustainable feedstocks and be easily accessible. Moreover, it should require only a minimum pretreatment, which must be performed at a low cost. Hydrogen has been produced from various raw materials including, barley straw, corn stalk, corn stover, corn cob, apple pomace (Urbaniec \& Bakker, 2015), fruit peel waste, wheat straw (Pawar, Nkemka, Zeidan, Murto, \& van Niel, 2013), cassava stillage (Luo, Xie, Zou, Zhou, \& Wang, 2010), sugar beet molasses (Urbaniec \& Grabarczyk, 2014), peach pulp (Argun \& Dao, 2017), sugarcane bagasse (Pattra, Sangyoka, Boonmee, \& Reungsang, 2008) and sugar cane stillage (Santos, Rosa, Sakamoto, Varesche, \& Silva, 2014). Furthermore, kitchen waste (Li \& Jin, 2015) and industrial waste like distillery effluents (Wicher, Seifert, Zagrodnik, Pietrzyk, \& Łaniecki, 2013), or starch-containing wastewater (Urbaniec \& Bakker, 2015) have also been applied.

The objective of this study was to investigate the dark fermentative production of hydrogen from various substrates of agri-food origin using different pretreatment strategies. The following raw materials were used in the research: sugar beet pulp, sugar beet leaves, sugar beet and rye stillage, maize silage, kitchen waste, and slaughterhouse waste. These materials, especially the ones of plant origin, are generated in large amounts whereas their utilization and disposal still creates great technological and environmental problems. In particular, the problem of sugar beet pulp, sugar beet leaves and stillage should be considered. Poland produces as much as 3.4 million tons of beet pulp in sugar factories the utilization of which in a traditional way can consume up to $40 \%$ of the total energy used in the plant for heating operations. Moreover, plant materials like beet pulp, leaves or maize silage tend to uncontrolled decomposition, especially when they are improperly prepared and stored. They are often not suitable for feeding animals due to the presence of harmful molds easily growing under low $\mathrm{pH}$ conditions. In light of this, production of hydrogen via dark fermentation could be an alternative to traditional utilization methods of agrifood materials also considering hydrogen as a clean form of energy with high calorific value. To the best of the authors' knowledge, this study is the first to investigate sugar beet pulp after steam and hydrolysis pretreatment, maize silage, rye stillage and sugar beet stillage as the feedstocks for hydrogen production.

\section{Material and methods}

\subsection{Inoculum characteristics}

Anaerobic sludge collected from the anaerobic mesophilic digester at the Municipal Wastewater Treatment Plant in Lodz, Poland was served as inoculum for the experiments. The inoculum had total and volatile solids concentrations of $25.34 \mathrm{~g} \mathrm{TS} / \mathrm{kg}$ and $16.00 \mathrm{~g} \mathrm{VS} / \mathrm{kg}$, respectively. The full characteristic of inoculum used in this study is shown in Table 1.

Table 1. Characteristics of substrates

\begin{tabular}{|c|c|c|c|c|c|c|c|c|c|}
\hline \multirow[b]{2}{*}{ Substrate } & \multicolumn{9}{|c|}{ Indicator } \\
\hline & $\begin{array}{c}\text { Total } \\
\text { solids (TS) }\end{array}$ & $\begin{array}{c}\text { Volatile } \\
\text { solids (VS) }\end{array}$ & $\begin{array}{l}\text { Chemical oxy- } \\
\text { gen demand } \\
\text { (COD) }\end{array}$ & Carbon & Nitrogen & $\begin{array}{l}\text { Phos- } \\
\text { phorus }\end{array}$ & Hydrogen & Sulfur & $\mathrm{C} / \mathrm{N}$ \\
\hline Unit & $\mathrm{g} / \mathrm{kg}$ & $\mathrm{g} / \mathrm{kg}$ & $\mathrm{gO}_{2} / \mathrm{kg}$ & $\%$ TS & $\%$ TS & $\%$ TS & $\%$ TS & $\%$ TS & - \\
\hline Inoculum & $25.34 \pm 0.81$ & $16.00 \pm 0.20$ & $2.90 \pm 0.06$ & $59.7 \pm 1.21$ & $3.20 \pm 0.23$ & $1.94 \pm 0.07$ & $5.90 \pm 0.12$ & $0.91 \pm 0.25$ & $18.66 \pm 1.24$ \\
\hline Rye stillage & $145.18 \pm 0.10$ & $122.83 \pm 0.26$ & $133.55 \pm 0.21$ & $65.1 \pm 0.89$ & $1.86 \pm 0.08$ & $0.11 \pm 0.02$ & $5.1 \pm 0.47$ & $0.29 \pm 0.01$ & $35.00 \pm 3.08$ \\
\hline $\begin{array}{l}\text { Fruit and } \\
\text { vegetable } \\
\text { wastes }\end{array}$ & $148.63 \pm 5.66$ & $127.06 \pm 4.78$ & $198.48 \pm 0.06$ & $59.7 \pm 1.87$ & $6.7 \pm 0.15$ & $0.29 \pm 0.1$ & $6.3 \pm 0.25$ & $0.04 \pm 0.00$ & $8.91 \pm 2.14$ \\
\hline $\begin{array}{l}\text { Sugar beet } \\
\text { leaves }\end{array}$ & $160.62 \pm 5.49$ & $138.74 \pm 4.54$ & $128.16 \pm 0.42$ & $61.3 \pm 1.54$ & $0.29 \pm 0.01$ & $0.02 \pm 0.00$ & $7.9 \pm 0.21$ & $0.02 \pm 0.00$ & $211.38 \pm 9.53$ \\
\hline $\begin{array}{l}\text { Maize } \\
\text { silage }\end{array}$ & $409.84 \pm 1.48$ & $396.73 \pm 4.78$ & $56.33 \pm 0.01$ & $63.1 \pm 0.24$ & $1.86 \pm 0.31$ & $0.11 \pm 0.01$ & $5.1 \pm 0.22$ & $0.02 \pm 0.00$ & $33.92 \pm 2.37$ \\
\hline $\begin{array}{l}\text { Sugar beet } \\
\text { stillage }\end{array}$ & $144.96 \pm 0.27$ & $122.60 \pm 0.45$ & $6.44 \pm 0.01$ & $62.3 \pm 0.57$ & $5.8 \pm 0.09$ & $4.92 \pm 0.14$ & $6.1 \pm 0.14$ & $0.36 \pm 0.01$ & $10.74 \pm 2.54$ \\
\hline $\begin{array}{l}\text { Sugar beet } \\
\text { pulp }\end{array}$ & $202.82 \pm 3.51$ & $193.36 \pm 3.90$ & $252.24 \pm 0.06$ & $69.8 \pm 1.02$ & $0.19 \pm 0.02$ & $0.02 \pm 0.00$ & $7.9 \pm 0.87$ & $0.02 \pm 0.00$ & $364.37 \pm 10.81$ \\
\hline $\begin{array}{l}\text { Intestinal } \\
\text { wastes }\end{array}$ & $258.61 \pm 1.32$ & $229.82 \pm 1.36$ & $346.53 \pm 0.01$ & $61.4 \pm 1.38$ & $9.69 \pm 1.65$ & $0.12 \pm 0.01$ & $4.9 \pm 0.35$ & $0.02 \pm 0.00$ & $6.34 \pm 1.72$ \\
\hline Meat tissue & $306.67 \pm 1.30$ & $288.56 \pm 1.74$ & $204.78 \pm 0.06$ & $62.1 \pm 0.56$ & $10.63 \pm 1.87$ & $0.09 \pm 0.00$ & $\begin{array}{l}4.8 \pm \\
0.76\end{array}$ & $0.01 \pm 0.00$ & $5.84 \pm 1.13$ \\
\hline $\begin{array}{l}\text { Post flota- } \\
\text { tion sludge }\end{array}$ & $261.90 \pm 1.78$ & $210.17 \pm 1.94$ & $70.40 \pm 0.01$ & $59.2 \pm 1.14$ & $3.45 \pm 1.08$ & $0.06 \pm 0.00$ & $5.8 \pm 0.39$ & $0.07 \pm 0.00$ & $17.16 \pm 2.41$ \\
\hline $\begin{array}{l}\text { Kitchen } \\
\text { wastes }\end{array}$ & $247.34 \pm 5.50$ & $237.39 \pm 8.66$ & $147.85 \pm 0.1$ & $58.4 \pm 1.78$ & $5.2 \pm 0.58$ & $0.29 \pm 0.01$ & $6.1 \pm 0.24$ & $0.32 \pm 0.02$ & $14.60 \pm 1.37$ \\
\hline \pm Stand & viation & & & & & & & & \\
\hline
\end{tabular}




\subsection{Substrate characteristics}

The experiments were performed using the following substrates: sugar beet (Beta vulgaris) pulp (fresh, hydrolyzed, autoclaved), sugar beet leaves, maize (Zea mays) silage, fruit and vegetable wastes, kitchen wastes, sugar beet stillage, rye stillage, slaughterhouse waste (meat tissue, intestinal wastes and post flotation sludge). Due to the seasonality of most substrates, the raw materials were stored at $-18{ }^{\circ} \mathrm{C}$ before use and the pretreatment was performed after thawing. Prior the fermentation process, the substrate were ground in a grinder (FIMAR TS-32D400V) to obtain the particles of $0.3-1.3 \mathrm{~cm}$ in diameter. Sugar beet pulp (SBP) was delivered from Dobrzelin Sugar Factory, Poland. Sugar beet pulp hydrolysates (SBPH) were obtained by enzymatic pretreatment of SBP using a mixture of two commercial multienzyme preparations: Viscozyme and Ultraflo Max (Novozymes, Denmark). The saccharification of sugar beet pulp was conducted at the temperature of $50^{\circ} \mathrm{C}$ and $\mathrm{pH}$ of 5.0 with mixing for $24 \mathrm{~h}$. Then, the hydrolysate was filtered to obtain the liquid and solid fractions. Fresh sugar beet leaves (SBL) from a farm in Dobrzelin were ground and then steamed in autoclave at $121{ }^{\circ} \mathrm{C}$ for 40 minutes. Maize silage was collected from a local farm in Bełchatów, Poland. Fruit and vegetable waste (FVW) as well as kitchen waste (KW) were daily collected in individual households. FVW were composed of fruit and vegetable residues exclusively, whereas kitchen waste also contained other wastes, including meat residues and non-biodegradable contaminants (large bones, egg shells). Kitchen waste as well as fruit and vegetable waste were collected for a few weeks, then ground and thoroughly mixed to prepare a relatively homogenous mass for all the experimental processes. Slaughterhouse waste: meat tissue, intestinal wastes and post flotation sludge, were collected at PINI Polonia Company in Kutno, Poland. Sugar beet stillage as well as rye stillage were byproducts of bioethanol production from an installation operated in Institute of Fermentation Technology and Microbiology, Lodz University of Technology. The characteristics of substrates used for the investigation are shown in Table 1.

\subsection{Experimental setup and operational conditions}

The experiments were performed using batch fermentation systems (Figure 1) consisting of $1 \mathrm{dm}^{3}$ glass bottles with a working volume of $0.7 \mathrm{dm} 3$. Each bottle was connected to a $1 \mathrm{dm}^{3}$ gas collecting tank to measure daily biogas production by a water displacement method as described elsewhere. The reactors were filled in with $0.5 \mathrm{~kg}$ of inoculum and then the substrates were added to achieve the inoculum to substrate $\left(\mathrm{X}_{\mathrm{o}} / \mathrm{S}_{\mathrm{o}}\right)$ ratio of 2:1 (g VSinoculum/g VSsubstrate) based on volatile solids concentration without any nutrient supplementation (Angelidaki et al., 2009; Tsapekos, Kougiasp, Treu, Campanaro, \& Angelidaki, 2017). Before shutting down, the headspace of each bottle was rinsed with nitrogen gas for 3 minutes to ensure anaerobic conditions. The bottles were then incubated at $35^{\circ} \mathrm{C}$ in a thermostat, which maintained constant mesophilic temperature, and they were manually shaken once a day. Each experiment was continued to the point at which only residual or no biogas production was measured. For each substrate, four experimental runs were performed as shown in Figure 1 - first variant: feedstock and inoculum without any pretreatment, second variant: with $\mathrm{pH}$ adjustment to 5.5 , third variant: with thermal pretreatment $\left(80^{\circ} \mathrm{C}\right.$ for $\left.1.5 \mathrm{~h}\right)$ and fourth variant: with $\mathrm{pH}$ adjustment and thermal pretreatment. These operations have been aimed to inactivate hydrogen consuming microorganisms (primarily methanogens) (Akobi, Hafez, \& Nakhla, 2016). The individual runs were performed in triplicates, the results of which are expressed as averages.

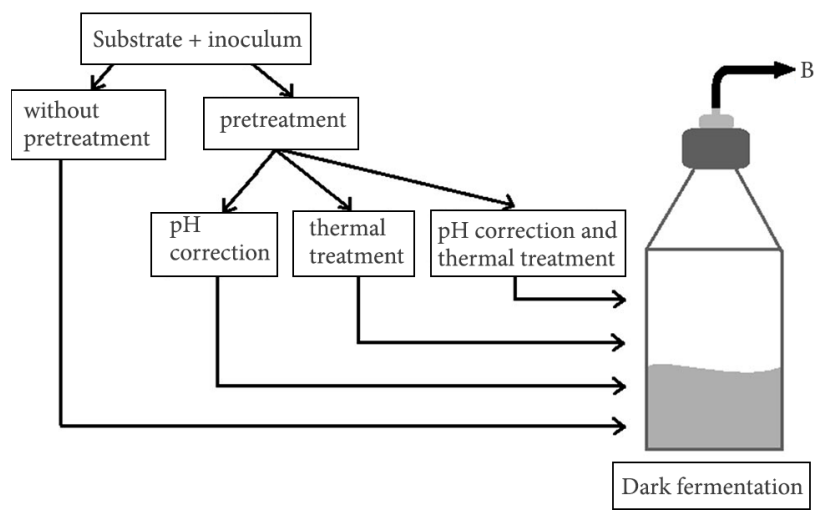

Figure 1. Schematic diagram of the experiments

\subsection{Analytical methods}

Total and volatile solids (TS, VS) as well as $\mathrm{pH}$ were analyzed based on Standard Methods for the Examination of Water and Wastewater (Rice, Baird, Eaton, \& Clesceri, 2012). Chemical oxygen demand (COD) was determined using a DR 6000 spectrophotometer and HACH-Lange test LCK914. Elemental analysis (C, N, H, P, S) was performed with a 2500 elemental analyzer (CE Instruments, UK) following the manufacturer's procedure. The total carbon was divided by the total nitrogen to obtain the $\mathrm{C} / \mathrm{N}$ ratio. Biogas yield was monitored on a daily basis by the water displacement method (Zhong et al., 2011). Biogas composition was analyzed using a portable gas analyzer (Madur, GA-21 plus).

The analyses of individual samples were performed in at least triplicates. The calculation of the average values, standard deviations, and the analysis of variance (single factor ANOVA) were performed in Microsoft Excel 2010. The significance of differences between experimental groups was calculated by Tukey's test ( $\mathrm{R}$ version 3.5.0) with an alpha level of $\mathrm{p}<0.05$.

\section{Results and discussion}

\subsection{Characteristics of substrates}

The characteristics of substrates and inoculum used in this study are depicted in Table 1 and 2. The inoculum had an average VS concentration of $16 \mathrm{~g} / \mathrm{kg}$, and the average COD 
value was $24.90 \mathrm{~g} \mathrm{O}_{2} / \mathrm{kg}$. The initial $\mathrm{pH}$ of the inoculum was in the range of 7.34-7.76. The substrates significantly differed in terms of both organics and nutrient contents. Sugar beet pulp had the highest carbon content of $69.8 \%$ TS, but also contained as low as $0.19 \%$ TS of nitrogen and $0.02 \%$ TS of phosphorus. This gives a very high $\mathrm{C} / \mathrm{N}$ ratio value of 364 for this substrate and suggests nutrient supplementation prior digestion. Likewise, sugar beet leaves were also poor in both nitrogen and phosphorus with the $\mathrm{C} / \mathrm{N}$ ratio of around 211 . The optimum range of $\mathrm{C} / \mathrm{N}$ ratio for classical anaerobic digestion was suggested to be 20-30 (Xia, Cheng, \& Murphy, 2016). However, for dark fermentation, this ratio differs, for example O-Thong, Prasertsana, Intrasungkhab, Dhamwichukornc, and Birkelandd (2008) reported an optimum hydrogen production at a $\mathrm{C} / \mathrm{N}$ ratio of 74 and a C/P ratio of 559. Contrary to sugar beet pulp and leaves, slaughterhouse wastes (especially meat tissue and intestinal wastes) were abundant in nitrogen but also poor in phosphorus.

\subsection{Batch experiments}

The results of the batch digestion tests are summarized in Tables 2-6, whereas the plots with cumulative biogas yields are shown in Figures 2 and 3. A statistical comparison of hydrogen yields from the individual substrates is depicted in Tables $1 S-4 S$ in supplementary materials.

Generally, the amount of produced hydrogen depends on several factors of which the substrate type, $\mathrm{pH}$ and pretreatment temperature play a crucial role. Heat pretreatment and acidic $\mathrm{pH}$ inactivate hydrogen consumers (mainly methanogens) whereas spore-forming bacteria (Clostridium sp., Bacillus sp.) responsible for hydrogen production easily survive (Lee, Ebie, $\mathrm{Xu}, \mathrm{Li}, \&$ Inamori,

Table 2. Parameters of the batch digestion tests

\begin{tabular}{|l|c|c|c|c|c|}
\hline \multicolumn{1}{|c|}{ Substrate } & $\begin{array}{c}\text { Mass of substrate } \\
{[\mathrm{g}]}\end{array}$ & $\begin{array}{c}\text { Substrate } \\
\text { VS }[\mathrm{g} / \mathrm{kg}]\end{array}$ & $\begin{array}{c}\text { Mass of inoculum } \\
{[\mathrm{g}]}\end{array}$ & $\begin{array}{c}\text { Inoculum } \\
\text { VS }[\mathrm{g} / \mathrm{kg}]\end{array}$ & $\begin{array}{c}\text { Duration time } \\
{[\mathrm{d}]}\end{array}$ \\
\hline Rye stillage & 33 & $122.83 \pm 0.26$ & 500 & $16.00 \pm 1.20$ & 14 \\
\hline Fruit and vegetable wastes & 28 & $127.06 \pm 4.78$ & 500 & $14.02 \pm 1.11$ & 14 \\
\hline Sugar beet stillage & 50 & $122.60 \pm 0.45$ & 500 & $18.77 \pm 1.02$ & 14 \\
\hline Intestinal wastes & 15 & $229.82 \pm 1.36$ & 500 & $14.02 \pm 1.11$ & 14 \\
\hline Meat tissue & 12 & $288.56 \pm 1.74$ & 500 & $14.02 \pm 1.11$ & 14 \\
\hline Post flotation sludge & 17 & $210.17 \pm 1.94$ & 500 & $14.02 \pm 1.11$ & 14 \\
\hline Kitchen wastes & 17 & $237.39 \pm 8.66$ & 500 & $18.77 \pm 1.02$ & 14 \\
\hline Maize silage & 12 & $127.06 \pm 4.78$ & 500 & $18.56 \pm 1.57$ & 14 \\
\hline Sugar beet leaves & 25 & $138.74 \pm 4.54$ & 500 & $18.56 \pm 1.57$ & 14 \\
\hline Fresh sugar beet pulp & 18 & $194.28 \pm 6.13$ & 500 & $14.02 \pm 1.11$ & 14 \\
\hline Hydrolyzed sugar beet pulp & 32 & $146.34 \pm 3.34$ & 500 & $18.77 \pm 1.02$ & 14 \\
\hline Steamed sugar beet pulp & 24 & $193.36 \pm 1.90$ & 500 & $18.56 \pm 1.57$ & 14 \\
\hline \pm Standard deviation & & & & & 14 \\
\hline
\end{tabular}

Table 3. Parameters of the batch digestion tests without pretreatment

\begin{tabular}{|l|c|c|c|}
\hline \multicolumn{1}{|c|}{ Substrate } & $\begin{array}{c}\text { Specific gas production (SGP) } \\
\mathrm{dm}^{3} / \mathrm{kg} \mathrm{VS}\end{array}$ & $\begin{array}{c}\text { Specific methane production } \\
(\mathrm{SMP}) \mathrm{dm}^{3} \mathrm{CH}_{4} / \mathrm{kg} \mathrm{VS}\end{array}$ & $\begin{array}{c}\text { Specific hydrogen production } \\
\left(\mathrm{SHP}^{2} \mathrm{dm}^{3} \mathrm{H}_{2} / \mathrm{kg} \mathrm{VS}^{\mathrm{V}}\right.\end{array}$ \\
\hline Rye stillage & $696.74 \pm 12.26$ & $33.04 \pm 3.65$ & $39.34 \pm 9.32$ \\
\hline Fruit and vegetable wastes & $649.93 \pm 42.9$ & $234.91 \pm 50.97$ & $102.83 \pm 23.24$ \\
\hline Sugar beet stillage & $508.43 \pm 12.58$ & $226.22 \pm 22.47$ & $109.26 \pm 9.45$ \\
\hline Intestinal wastes & $680.94 \pm 54.35$ & $421.20 \pm 21.71$ & $74.23 \pm 6.11$ \\
\hline Meat tissue & $1096.68 \pm 31.65$ & $782.33 \pm 0.55$ & $30.36 \pm 1.57$ \\
\hline Post flotation sludge & $637.44 \pm 10.89$ & $280.18 \pm 39.43$ & $47.74 \pm 0.69$ \\
\hline Kitchen wastes & $613.56 \pm 45.83$ & $270.30 \pm 21.36$ & $88.13 \pm 12.49$ \\
\hline Maize silage & $545.08 \pm 48.26$ & $242.40 \pm 56.15$ & $116.73 \pm 21.47$ \\
\hline Sugar beet leaves & $378.49 \pm 36.21$ & $180.57 \pm 21.45$ & $31.53 \pm 1.13$ \\
\hline Fresh sugar beet pulp & $230.91 \pm 3.03$ & $125.34 \pm 6.34$ & $11.20 \pm 6.79$ \\
\hline Hydrolyzed sugar beet pulp & $1032.31 \pm 89.27$ & $389.91 \pm 24.15$ & $143.43 \pm 24.11$ \\
\hline Steamed sugar beet pulp & $923.08 \pm 68.85$ & $416.12 \pm 23.59$ & $121.12 \pm 25.39$ \\
\hline
\end{tabular}


Table 4. Parameters of the batch digestion tests with $\mathrm{pH}$ adjustment

\begin{tabular}{|l|c|c|c|}
\hline \multicolumn{1}{|c|}{ Substrate } & $\begin{array}{c}\text { Specific gas production (SGP) } \\
\mathrm{dm}^{3} / \mathrm{kg} \mathrm{VS}\end{array}$ & $\begin{array}{c}\text { Specific methane production } \\
(\mathrm{SMP}) \mathrm{dm}^{3} \mathrm{CH}_{4} / \mathrm{kg} \mathrm{VS}\end{array}$ & $\begin{array}{c}\text { Specific hydrogen production } \\
(\mathrm{SHP}) \mathrm{dm}^{3} \mathrm{H}_{2} / \mathrm{kg} \mathrm{VS}^{\mathrm{V}}\end{array}$ \\
\hline Rye stillage & $193.28 \pm 5.57$ & $2.15 \pm 0.57$ & $31.87 \pm 5.17$ \\
\hline Fruit and vegetable wastes & $302.82 \pm 57.17$ & $1.71 \pm 0.28$ & $94.9 \pm 17.56$ \\
\hline Sugar beet stillage & $386.27 \pm 45.73$ & $3.26 \pm 0.89$ & $51.16 \pm 2.49$ \\
\hline Intestinal wastes & $151.56 \pm 32.29$ & $74.84 \pm 8.94$ & $8.02 \pm 1.33$ \\
\hline Meat tissue & $398.53 \pm 59.22$ & $127.59 \pm 19.39$ & $26.39 \pm 8.67$ \\
\hline Post flotation sludge & $197.32 \pm 15.21$ & $57.40 \pm 3.11$ & $62.62 \pm 2.54$ \\
\hline Kitchen wastes & $338.18 \pm 21.47$ & $4.15 \pm 0,56$ & $74.74 \pm 3.24$ \\
\hline Maize silage & $181.17 \pm 24.83$ & $2.39 \pm 0.49$ & $25.46 \pm 1.36$ \\
\hline Sugar beet leaves & $121.52 \pm 22.39$ & $1.17 \pm 0.09$ & $13.58 \pm 6.65$ \\
\hline Fresh sugar beet pulp & $130.82 \pm 38.51$ & $34.68 \pm 4.50$ & $77.85 \pm 8.37$ \\
\hline Hydrolyzed sugar beet pulp & $407.16 \pm 35.61$ & $13.56 \pm 1.25$ & $61.75 \pm 12.74$ \\
\hline Steamed sugar beet pulp & $177.95 \pm 30.19$ & $2.78 \pm 0.01$ & \\
\hline
\end{tabular}

Table 5. Parameters of the batch digestion tests with thermal pretreatment

\begin{tabular}{|l|c|c|c|}
\hline \multicolumn{1}{|c|}{ Substrate } & $\begin{array}{c}\text { Specific gas production (SGP) } \\
\mathrm{dm}^{3} / \mathrm{kg} \mathrm{VS}\end{array}$ & $\begin{array}{c}\text { Specific methane production } \\
(\mathrm{SMP}) \mathrm{dm}^{3} \mathrm{CH}_{4} / \mathrm{kg} \mathrm{VS}\end{array}$ & $\begin{array}{c}\text { Specific hydrogen production } \\
(\mathrm{SHP}) \mathrm{dm}^{3} \mathrm{H}_{2} / \mathrm{kg} \mathrm{VS}\end{array}$ \\
\hline Rye stillage & $377.78 \pm 77.44$ & $14.90 \pm 1.14$ & $8.98 \pm 3.72$ \\
\hline Fruit and vegetable wastes & $339.41 \pm 33.94$ & $0.71 \pm 0.99$ & $97.69 \pm 10.82$ \\
\hline Sugar beet stillage & $287.27 \pm 24.19$ & $94.26 \pm 13.64$ & $45.14 \pm 18.39$ \\
\hline Intestinal wastes & $575.06 \pm 50.25$ & $389.53 \pm 30.58$ & $56.38 \pm 7.18$ \\
\hline Meat tissue & $30.32 \pm 2.04$ & $0.00 \pm 0.00$ & $0.00 \pm 0.00$ \\
\hline Post flotation sludge & $447.82 \pm 1.97$ & $244.89 \pm 17.19$ & $49.33 \pm 14.72$ \\
\hline Kitchen wastes & $236.73 \pm 28.14$ & $6.42 \pm 1.37$ & $51.46 \pm 12.57$ \\
\hline Maize silage & $218.45 \pm 32.24$ & $0.61 \pm 0.05$ & $268.78 \pm 24.16$ \\
\hline Sugar beet leaves & $25.32 \pm 2.14$ & $0.00 \pm 0.00$ & $0.00 \pm 0.00$ \\
\hline Fresh sugar beet pulp & $278.09 \pm 3.03$ & $71.94 \pm 5.72$ & $30.85 \pm 7.69$ \\
\hline Hydrolyzed sugar beet pulp & $317.47 \pm 24.16$ & $5.34 \pm 0.78$ & $150.98 \pm 5.24$ \\
\hline Steamed sugar beet pulp & $170.84 \pm 60.39$ & $1.56 \pm 0.54$ & $102.02 \pm 19.61$ \\
\hline
\end{tabular}

Table 6. Parameters of the batch digestion tests with $\mathrm{pH}$ adjustment and thermal pretreatment

\begin{tabular}{|l|c|c|c|}
\hline \multicolumn{1}{|c|}{ Substrate } & $\begin{array}{c}\text { Specific gas production (SGP) } \\
\mathrm{dm}^{3} / \mathrm{kg} \mathrm{VS}\end{array}$ & $\begin{array}{c}\text { Specific methane production } \\
(\mathrm{SMP}) \mathrm{dm}^{3} \mathrm{CH}_{4} / \mathrm{kg} \mathrm{VS}\end{array}$ & $\begin{array}{c}\text { Specific hydrogen production } \\
(\mathrm{SHP}) \mathrm{dm}^{3} \mathrm{H}_{2} / \mathrm{kg} \mathrm{VS}\end{array}$ \\
\hline Rye stillage & $203.53 \pm 9.29$ & $8.23 \pm 1.67$ & $104.75 \pm 2.28$ \\
\hline Fruit and vegetable wastes & $523.63 \pm 8.92$ & $0.00 \pm 0.00$ & $280.33 \pm 14.5$ \\
\hline Sugar beet stillage & $152.56 \pm 12.14$ & $5.03 \pm 0.54$ & $76.94 \pm 16.32$ \\
\hline Intestinal wastes & $0.00 \pm 0.00$ & $0.00 \pm 0.00$ & $0.00 \pm 0.00$ \\
\hline Meat tissue & $7.22 \pm 0.21$ & $0.00 \pm 0.00$ & $0.00 \pm 0.00$ \\
\hline Post flotation sludge & $129.45 \pm 32.66$ & $0.00 \pm 0.00$ & $0.00 \pm 0.00$ \\
\hline Kitchen wastes & $232.00 \pm 22.15$ & $0.13 \pm 0.08$ & $53.45 \pm 2.47$ \\
\hline Maize silage & $157.54 \pm 8.37$ & $0.00 \pm 0.00$ & $115.28 \pm 20.57$ \\
\hline Sugar beet leaves & $91.77 \pm 2.15$ & $2.25 \pm 0.29$ & $5.69 \pm 1.28$ \\
\hline Fresh sugar beet pulp & $14.30 \pm 0.12$ & $1.03 \pm 0.23$ & $6.17 \pm 1.38$ \\
\hline Hydrolyzed sugar beet pulp & $364.00 \pm 12.53$ & $4.88 \pm 1.24$ & $212.17 \pm 17.59$ \\
\hline Steamed sugar beet pulp & $76.16 \pm 17.25$ & $0.00 \pm 0.00$ & $34.90 \pm 1.55$ \\
\hline
\end{tabular}


2010; Sikora, Błaszczyk, Jurkowski, \& Zielenkiewicz, 2013). In our experiments, $\mathrm{pH}$ of the samples before digestion was adjusted to 5.5 , which was a value within an optimal range for dark fermentative hydrogen production reported in the literature (Ghimire et al., 2015; Guo, Trably, Latrinne, Carrere, \& Steyer, 2010). As shown in Tables 3-6, the experiments with neither $\mathrm{pH}$ correction nor thermal pretreatment gave the highest biogas yields, but the main biogas component was methane. The highest biogas productions of $1097 \mathrm{dm}^{3} / \mathrm{kg}$ VS and $681 \mathrm{dm}^{3} / \mathrm{kg}$ VS were obtained for meat tissue and intestinal wastes, respectively, which corresponded to the methane yields of $782 \mathrm{dm}^{3}$ $\mathrm{CH}_{4} / \mathrm{kg} \mathrm{VS}$ and $421 \mathrm{dm}^{3} \mathrm{CH}_{4} / \mathrm{kg} \mathrm{VS}$, respectively. Regarding the substrates of plant origin, the greatest biogas yields of $1032 \mathrm{dm}^{3} / \mathrm{kg}$ VS and $923 \mathrm{dm}^{3} / \mathrm{kg}$ were achieved for hydrolyzed and steamed sugar beet pulp, and the corresponding methane yields reached $390 \mathrm{dm}^{3} \mathrm{CH}_{4} / \mathrm{kg}$ VS and $416 \mathrm{dm}^{3} \mathrm{CH}_{4} / \mathrm{kg}$ VS. Moreover, the cumulative hydrogen yields from hydrolyzed and steamed SBP reached $143 \mathrm{dm}^{3}$ $\mathrm{H}_{2} / \mathrm{kg}$ VS and $121 \mathrm{dm}^{3} \mathrm{H}_{2} / \mathrm{kg}$ VS, respectively, and these values were the highest among all the experiments performed without any pretreatment (Table 3 ). The cumulative hydrogen yield of over $100 \mathrm{dm}^{3} \mathrm{CH}_{4} / \mathrm{kg}$ VS was also reported for sugar beet stillage, maize silage and fruit and vegetable waste, and the statistical analysis showed no significant differences in hydrogen production between these substrates (Table 1S).

The $\mathrm{pH}$ adjustment alone did not significantly improve hydrogen production as the specific yields of this gas did not exceed $100 \mathrm{dm}^{3} / \mathrm{kg}$ VS (Table 4 ). The heat pretreatment followed by the $\mathrm{pH}$ correction to 5.5 was needed to achieve considerable hydrogen yields and to inhibit methane production. As reported in the literature (Lee et al., 2010) heat treatment inactivates most hydrogen consumers. The highest specific hydrogen production after combined pretreatment was achieved for fruit and vegetable yields ( $280 \mathrm{dm}^{3} \mathrm{CH}_{4} / \mathrm{kg}$ VS) and for hydrolyzed sugar beet pulp (212 $\mathrm{dm}^{3} \mathrm{CH}_{4} / \mathrm{kg}$ VS). The hydrogen yield greater than $100 \mathrm{dm}^{3} \mathrm{CH}_{4} / \mathrm{kg}$ VS was also achieved for maize silage, rye stillage and steamed SBP (Table 5). Only trace amounts of methane not exceeding $5 \mathrm{dm}^{3} \mathrm{CH}_{4} / \mathrm{kg} \mathrm{VS}$ were recorded for these substrates. Interestingly, the hydrogen production from maize silage was 4-fold higher that the yields obtained from similar substrate in the study of Benito Martin, Schlienz, and Greger (2017). The statistical analysis showed that the production of hydrogen from fruit and vegetable waste as well as hydrolyzed SBP (both exceeding $200 \mathrm{dm}^{3} \mathrm{H}_{2} / \mathrm{kg}$ VS) was significantly higher $(\mathrm{p}<0.05)$ compared to the other substrates after combined $\mathrm{pH}$ and thermal pretreatment (Table $4 \mathrm{~S}$ ). It is interesting to note, that maize silage produced as high as $269 \mathrm{dm}^{3} / \mathrm{kg}$ VS of hydrogen in the experiment with only thermal pretreatment (Table 5), whereas the hydrogen yields in the samples after $\mathrm{pH}$ adjustment did not exceed $115 \mathrm{dm}^{3} / \mathrm{kg}$ VS (Table 4). This finding might be linked to the high lactic acid production from maize silage reported in the literature and its negative impact on dark fermentation. In the literature, there are only few reports on the use of maize silage for hydrogen production. Generally, most reports have focused on the anaerobic co-digestion of maize silage with other organic substrates. Likewise sugar beet pulp, maize silage is abundant in polysaccharides, mainly hemicelluloses (17.9\% TS) and cellulose (17.5\% TS), whereas the content of lignin is relatively low (1.07\% TS) (Benito Martin et al., 2017). The anaerobic digestion process of ensilaged substrates is characterized by an occurrence of lactic acid bacteria (LAB), particularly in its first phase. Sikora el al. (2013) observed the presence of LAB (mainly Leuconostocaeae) in hydrogen-producing consortia with Clostridiaceae as predominant ones. A potential impact of lactic acid bacteria on dark fermentation still remains unknown. Noike, Takabatake, Mizuno, and Ohba (2002) as well as Ren et al. (2007) observed competition for substrate between hydrogen producers and $\mathrm{LAB}$, which led to lower hydrogen yield. Moreover, an inhibitory effect of LAB on hydrogen yield is strongly dependent on $\mathrm{pH}$ and the digestion temperature. Noike et al. (2002) have also suggested the use of thermal pretreatment as an effective method of $\mathrm{LAB}$ inactivation. In contrast to these findings, some scientists suggest a positive effect of LAB activity on hydrogen production (Yang, Zhang, McGarvey, \& Benemann, 2007). During the dark fermentation process, lactates and acetates are converted to butyrates with the release of hydrogen (Chojnacka et al., 2011). Furthermore, Yang et al. (2007) have found that some lactic acid bacteria are able to produce hydrogen. However, these speculations are not fully recognized and need to be confirmed.

Regarding methane production during dark fermentation, it might be concluded that significantly higher and more stable yield of this gas was observed in the experiments with no thermal pretreatment. Moreover, lower hydrogen yield could be linked to the simultaneous $\mathrm{H}_{2}$ and $\mathrm{CH}_{4}$ production, despite $\mathrm{pH}$ adjustment. As mentioned earlier, inoculum used for the experiments derived from the anaerobic digester treating municipal sewage sludge. Such inoculum has a variety of anaerobic microorganisms including methanogens including species capable of growing at low $\mathrm{pH}$. Hence, $\mathrm{pH}$ adjustment with no thermal pretreatment does not guarantee a complete inactivation of methanogens and lack of methane in biogas. Furthermore, some Archae species like Methanosaeta or Methanospharea metabolize $\mathrm{H}_{2}$ and $\mathrm{CO}_{2}$ to methane, and use formic acid or alcohols (mainly methanol) as electron donors (Akobi et al., 2016). Another group of microorganisms involved in hydrogen consumption are homoacetogenic bacteria. As reported in the literature, homoacetogenesis can consume $11-43 \%$ of H2 yielded in batch tests (Saady, 2013). Moreover, homoacetogenic bacteria can compete for the substrate with hydrogenothropic methanogens and utilize $\mathrm{H}_{2}$ to reduce $\mathrm{CO}_{2}$ to acetic acid. The presence of $\mathrm{H}_{2}$ in anaerobic reactor can had a positive effect on methanogenesis and no identified negative effect on acetogenesis (Saady, 2013). 
Regarding the other carbohydrate-rich substrates fresh sugar beet leaves and fresh sugar beet pulp - they produced almost no hydrogen, even in the experiments with the $\mathrm{pH}$ correction and thermal pretreatment (Table 6). This can be linked to the structure of these materials, mainly composed of lignocellulostic substances. As reported in the literature, sugar beet pulp is mainly composed of polysaccharides ( $41-61 \%$ hemicelluloses, $20-24 \%$

a)

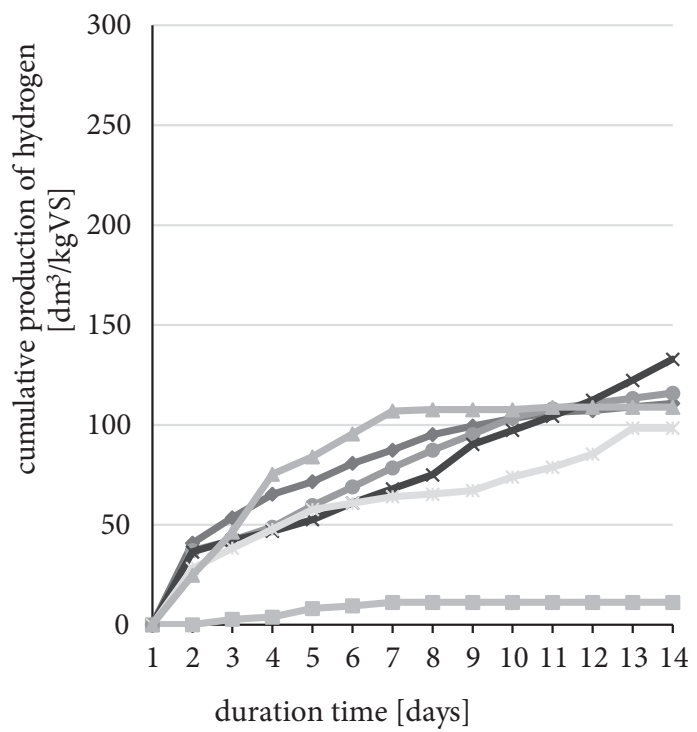

c)



cellulose, $1-2 \%$ lignin), which form a dense, complex structure. Other components of SBP are proteins, which constitute around $7-8 \%$ of its dry mass (Dredge, van Dyk, Radloff, \& Pletschke, 2011). In view of the above, fresh sugar beet pulp is hardly decomposed by microorganisms (Akobi et al., 2016). However, approximately $60-70 \%$ of its dry mass are potentially available polysaccharides $(\mathrm{Pa}-$ nagiotopoulos et al., 2010), which makes sugar beet pulp

b)



d)

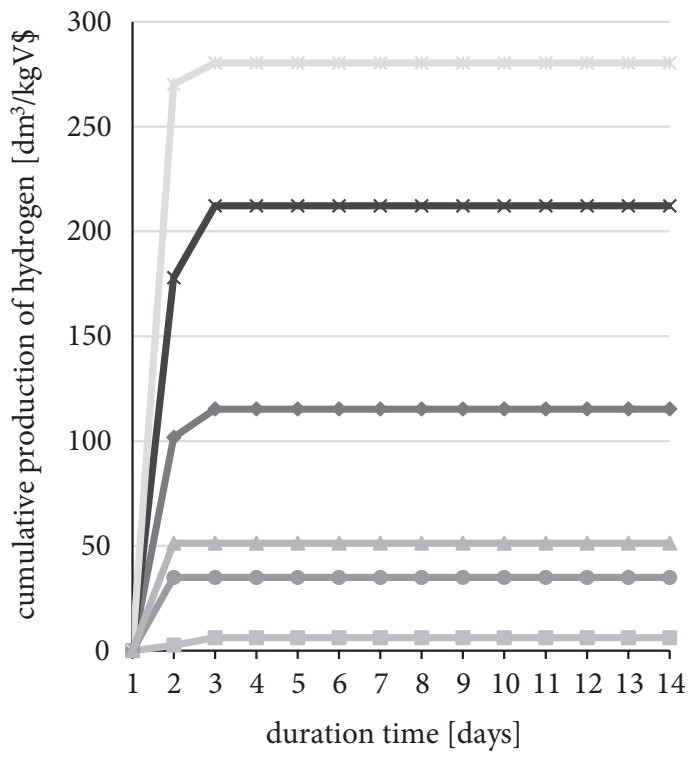

Figure 2. Cumulative hydrogen production a) - without correction, b) - with $\mathrm{pH}$ adjustment, c) - with thermal correction, d) with $\mathrm{pH}$ adjustment and thermal correction in batch experiments from MS, steamed SBP, hydrolyzed SBP, fresh SBP, FVW and KW 
attractive for hydrogen production. In our research, sugar beet pulp was preliminary treated by steaming or by means of two commercial multienzyme preparations: Viscozyme and Ultraflo Max. These operations significantly improved both hydrogen and methane production, especially enzymatic pretreatment enabled as much as $212 \mathrm{dm}^{3} / \mathrm{kg}$ VS of hydrogen (as discussed above) to be achieved, in contrast to $6 \mathrm{dm}^{3} / \mathrm{kg}$ VS obtained for fresh SBP (Table 6). The experiments have also confirmed that sugar beet pulp is relatively susceptible to any pretreatment due to a relatively

a)

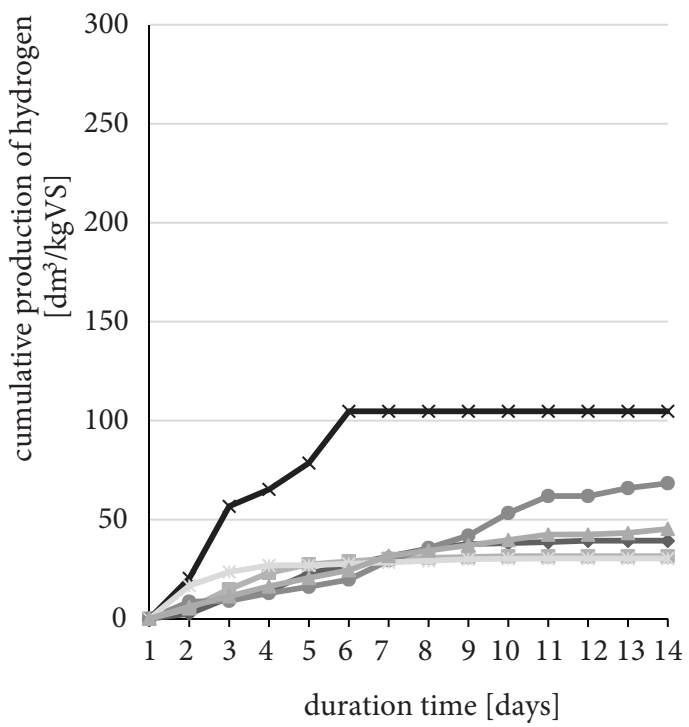

c)



low content of lignin, compared to other materials of plant origin (Panagiotopoulos et al., 2010). The effect of different pretreatment methods (alkaline, thermal, microwave, thermal-alkaline and microwave-alkaline) on hydrogen production was also studied by Ozkan et al. (2011). These authors achieved cumulative hydrogen yields in the range of $112-149 \mathrm{dm}^{3}$ whereas the samples with no pretreatment produced only $0.096 \mathrm{dm}^{3}$ of hydrogen.

Considering slaughterhouse wastes, they were confirmed to be well-suitable substrates for methane

b)

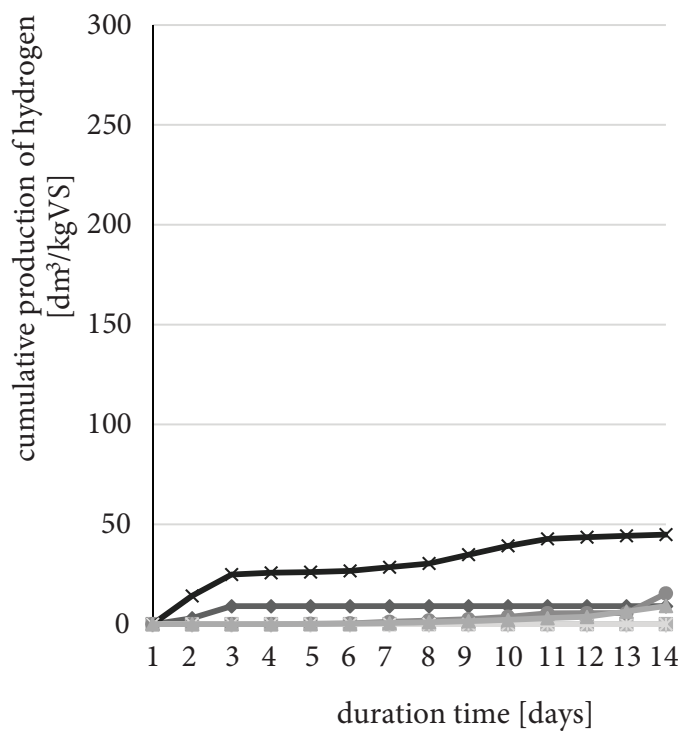

d)



$$
\begin{aligned}
& \multimap \text { rye stillage } \\
& - \text { sugar beet leaves } \\
& \leftarrow \text { intestinal wastes } \\
& * \text { sugar beet stillage } \\
& - \text { meat tissue } \\
& \leftarrow \text { post flotation sludge }
\end{aligned}
$$

Figure 3. Cumulative hydrogen production a) - without correction, b) - with $\mathrm{pH}$ adjustment, c) - with thermal correction, d) - with pH adjustment and thermal correction in batch experiments from RS, SBL, SBS and SHW 
production. In this study, the highest methane yield of $782.33 \mathrm{dm}^{3} \mathrm{CH}_{4} / \mathrm{kg}$ VS was achieved for meat tissue in the experiment without any pretreatment (Table 3 ). However, these substrates were found to be not suitable for hydrogen production, which can be linked to the high contents of lipids and proteins and low concentrations of carbohydrates. Proteins are firstly decomposed to amino acids, which, in turn, are fermented in pairs via Strickland reactions with no hydrogen yield (Hallenbeck, 2009). Lipids, in turn, are hydrolyzed to glycerol and long chain fatty acids. Furthermore, decomposition of slaughterhouse waste leads to accumulation of volatile fatty acids, sulfides and ammonia (Ghimire et al., 2015; Cuetos, Gómez, Otero, \& Morán, 2010). Fatty acids are then decomposed to acetates and hydrogen by syntrophic bacteria, but this process is only possible at a very low hydrogen partial pressure, which can only be provided by an activity of hydrogen consuming methanogens (Hallenbeck, 2009). Furthermore, LCFAa may also cause problems in dark fermentation because these compounds are toxic to various anaerobic microorganisms including acetogens, which are involved in hydrogen production (Angelidaki \& Ahring, 1992). These findings may also explain the differences between hydrogen production from fruit and vegetable wastes and kitchen wastes in our study. Fruit and vegetable waste exhibited the highest hydrogen yield of $280 \mathrm{dm}^{3} / \mathrm{kg}$ VS among all tested substrates, whereas the corresponding value for kitchen waste was only $53 \mathrm{dm}^{3} \mathrm{H}_{2} / \mathrm{kg}$ VS (Table 6). For comparison, Li, Zhao, Guo, Qijan, and Niu (2008) obtained $196 \mathrm{dm}^{3} \mathrm{H}_{2} / \mathrm{kg}$ VS from kitchen waste whereas Lay et al. (2005) yielded $125 \mathrm{dm}^{3} \mathrm{H}_{2} / \mathrm{kg}$ VS, and both cited authors used similar conditions in their research. Significantly different hydrogen yields obtained from fruit and vegetable waste and kitchen waste can be attributed to the compositions of both waste types. Fruit and vegetable wastes are exclusively composed of plant biomass abundant in carbohydrates, while kitchen wastes, apart from FVW, contain other edible components, including meat and fish residues, mayonnaise and sauces, rise, noodles etc. Many of these ingredients are not suitable for hydrogen production due to the high content of lipids and proteins. Interestingly, both substrates (FVW and $\mathrm{KW}$ ) gave similar, moderate methane yields of $235-270 \mathrm{dm}^{3} / \mathrm{kg}$ VS in the experiments with no pretreatment (Table 3). This might have been due to a $\mathrm{C} / \mathrm{N}$ balance of fresh substrate far from optimal for anaerobic digestion.

\section{Conclusions}

Batch tests have been found to be effective in showing the potential of hydrogen production from various substrates of plant and animal origin.

It was confirmed that the materials of plant origin were generally much more susceptible to dark fermentation, even without any pretreatment, compared to the substrates rich in proteins and fats.

A cumulative hydrogen yield greater than $100 \mathrm{dm}^{3}$ $\mathrm{H}_{2} / \mathrm{kg}$ VS was obtained from fruit and vegetable waste, sugar beet pulp stillage, maize silage as well as steamed and hydrolyzed sugar beet pulp.

Hydrogen production from plant waste and biomass was considerably improved by applying thermal pretreatment and $\mathrm{pH}$ adjustment to 5.5 in order to inhibit methanogens and stimulate hydrogen producers. In particular, fruit and vegetable waste yielded around $280 \mathrm{dm}^{3}$ $\mathrm{H}_{2} / \mathrm{kg}$ VS whereas maize stillage nearly $270 \mathrm{dm}^{3} \mathrm{H}_{2} / \mathrm{kg}$ VS.

However, some carbohydrate-rich substrates needed additional preliminary treatment to be suitable for hydrogen production. Especially, sugar beet pulp subjected to hydrolysis followed by thermal pretreatment and $\mathrm{pH}$ adjustment gave a hydrogen yield of $212 \mathrm{dm}^{3} / \mathrm{kg}$ VS in contrast to almost no hydrogen production from fresh SBP.

It was also reported that slaughterhouse waste and kitchen waste are not suitable for hydrogen production but they have high potential of methanation, whereas hydrolyzed sugar beet pulp can successfully be used to produce both gases.

\section{References}

Akobi, C., Hafez, H., \& Nakhla, G. (2016). The impact of furfural concentrations and substrate-to-biomass ratios on biological hydrogen production from synthetic lignocellulosic hydrolysate using mesophilic anaerobic digester sludge. Bioresource Technology, 221, 598-606.

https://doi.org/10.1016/j.biortech.2016.09.067

Angelidaki, I., \& Ahring, B. K. (1992). Effects of free long-chain fatty-acids on thermophilic anaerobic digestion. Applying Microbiology and Biotechnology, 37, 808-812.

https://doi.org/10.1007/BF00174850

Angelidaki, I., Alves, M., Bolzonella, D., Borzacconi, L., Campos, J. L., Guwy, A. J., Kalyuzhnyi, S., Jenicek, P., \& van Lier, J. B. (2009). Defining the biomethane potential (BMP) of solid organic wastes and energy crops: a proposed protocol for batch assays. Water Science \& Technology, 59(5), 927-934.

Argun, H., \& Dao, S. (2017). Bio-hydrogen production from waste peach pulp by dark fermentation: Effect of inoculums addition. International Journal of Hydrogen Energy, 26, 25692574. https://doi.org/10.1016/j.ijhydene.2016.06.225

Benito Martin, P. C., Schlienz, M., \& Greger, M. (2017). Production of bio-hydrogen and methane during semi-continuous digestion of maize silage in a two-stage system. International Journal of Hydrogen Energy, 42, 5768-5779.

https://doi.org/10.1016/j.ijhydene.2017.01.020

Chojnacka, A., Błaszczyk, M. K., Szczęsny, P., Nowak, K., Sumińska, M., Tomczyk-Żak, K., Zielenkiewicz, U., \& Sikora, A. (2011). Comparative analysis of hydrogen-producing bacterial biofilms and granular sludge formed in continuous cultures of fermentative bacteria. Bioresource Technology, 102, 10057-10064. https://doi.org/10.1016/j.biortech.2011.08.063

Chu, C.-F., Li, Y.-Y., Xu, K.-Q., Ebie, Y., Inamori, Y., Kong, H.-N. (2008). A pH- and temperature-phased two-stage process for hydrogen and methane production from food waste. International Journal of Hydrogen Energy, 33, 4739-4746. https://doi.org/10.1016/j.ijhydene.2008.06.060

Cuetos, M. J., Gómez, X., Otero, M., \& Morán, A. (2010). Anaerobic digestion and co-digestion of slaughterhouse waste (SHW): Influence of heat and pressure pre-treatment in biogas yield. Waste Management, 30, 1780-1789. https://doi.org/10.1016/j.wasman.2010.01.034 
Dredge, R., van Dyk, S. J., Radloff, S. E., \& Pletschke, B. I. (2011). Lime pretreatment of sugar beet pulp and evaluation of synergy between ArfA, ManA and XynA from Clostridium cellulovorans on the pretreated substrate. Biotechnology, 3, 151159. https://doi.org/10.1007/s13205-011-0019-3

Escamilla-Alvarado, C., Rios-Leal, E., Ponce-Noyola, M. T., \& Poggi-Varaldo, H. M. (2012). Gas biofuels from solid substrate hydrogenogenic-methanogenic fermentation of the organic fraction of municipal solid waste. Process Biochemistry, 47, 1572-15878. https://doi.org/10.1016/j.procbio.2011.12.006

Fang, H. H. P., Zhang, T., \& Liu, H. (2002). Microbial diversity of a mesophilic hydrogen producing sludge. Applying Microbiology and Biotechnology, 5, 112-118. https://doi.org/10.1007/s00253-001-0865-8

Ghimire, A., Frunzo, L., Pirozzi, F., Trably, E., Escudie, R., Lens, P. N. L., \& Esposito, G. (2015). A review on dark fermentative biohydrogen production from organic biomass: Process parameters and use of by-products. Applying Energy, 144, 73-95. https://doi.org/10.1016/j.apenergy.2015.01.045

Guo, X. M., Trably, E., Latrinne, E., Carrere, H., \& Steyer, J. P. (2010). Hydrogen production from agricultural waste by dark fermentation: A review. International Journal of Hydrogen Energy, 35, 10660-10673.

https://doi.org/10.1016/j.ijhydene.2010.03.008

Hallenbeck, P. C. (2009). Fermentative hydrogen production: Principles, progress, and prognosis. International Journal of Hydrogen Energy, 34, 7379-7389. https://doi.org/10.1016/j. ijhydene.2008.12.080

Lay, J., Fan, K., Hwang, J., Cgng, J., \& Hsu, P. (2005). Factors affecting hydrogen production from food wastes by Clostridium-rich composts. Journal Environmental Energy, 131(4), 595-602.

Lee, D.-Y., Ebie, Y., Xu, K.-Q., Li, Y.-Y., \& Inamori, Y. (2010). Continuous $\mathrm{H}_{2}$ and $\mathrm{CH}_{4}$ production from high-solid food waste in the two-stage thermophilic fermentation process with the recirculation of digester sludge. Bioresource Technology, 101, 42-47. https://doi.org/10.1016/j.biortech.2009.03.037

Li, M., Zhao, Y., Guo, Q., Qijan, X., \& Niu, D. (2008). Bio-hydrogen production from food waste and sewage sludge in the presence of aged refuse excavated from refuse landfill. Renewable Energy, 33 (12), 2573-2579.

https://doi.org/10.1016/j.renene.2008.02.018

Li, Y., \& Jin, Y. (2015). Effects of thermal pretreatment on acidification phase during two-phase batch anaerobic digestion of kitchen waste. Renewable Energy, 77, 550-557. https://doi.org/10.1016/j.renene.2014.12.056

Luo, G., Xie, L., Zou, Z. H., Zhou, Q., \& Wang, J. Y. (2010). Fermentative hydrogen production from cassava stillage by mixed anaerobic microflora: Effects of temperature and $\mathrm{pH}$. Applying Energy, 87, 3710-3717.

https://doi.org/10.1016/j.apenergy.2010.07.004

Noike, T., Takabatake, H., Mizuno, O., \& Ohba, M. (2002). Inhibition of hydrogen fermentation of organic wastes by lactic acid bacteria. International Journal of Hydrogen Energy, 27, 1367-1371. https://doi.org/10.1016/S0360-3199(02)00120-9

O-Thong, S., Prasertsana, P., Intrasungkhab, N., Dhamwichukornc, S., \& Birkelandd, N. K. (2008). Optimization of simultaneous thermophilic fermentative hydrogen production and COD reduction from palm oil mill effluent by Thermoanaerobacterium-rich sludge. International Journal of Hydrogen Energy, 33, 1221-1231.

https://doi.org/10.1016/j.ijhydene.2007.12.017

Ozkan, L., Erguder, T. H., \& Demirer, G. N. (2011). Effect of pretreatment methods on solubilization of beet-pulp and bio- hydrogen production yield. International Journal of Hydrogen Energy, 36, 382-389.

https://doi.org/10.1016/j.ijhydene.2010.10.006

Panagiotopoulos, J. A., Bakker, R. R., de Vrije, T., Urbaniec, K., Koukiose, G., \& Claassen, P. A. M. (2010). Prospects of utilization of sugar beet carbohydrates for biological hydrogen production in the EU. Journal Cleaner Production, 18, 9-14. https://doi.org/10.1016/j.jclepro.2010.02.025

Pattra, S., Sangyoka, S., Boonmee, M., \& Reungsang, A. (2008). Bio-hydrogen production from the fermentation of sugarcane bagasse hydrolysate by Clostridium butyricum. International Journal of Hydrogen Energy, 33, 5256-5265. https://doi.org/10.1016/j.ijhydene.2008.05.008

Pawar, S. S., Nkemka, V. N., Zeidan, A. A., Murto, M., \& van Niel, E. W. J. (2013). Biohydrogen production from wheat straw hydrolysate using Caldicellulosiruptor saccharolyticus followed by biogas production in a two-step uncoupled process. International Journal of Hydrogen Energy, 38, 9121-9130. https://doi.org/10.1016/j.ijhydene.2013.05.075

Ren, N., Xing, D., Rittmann, B. E., Zhao, L., Xie, T., \& Zhao, X. (2007). Microbial community structure of ethanol type fermentation in bio-hydrogen production. Environmental Microbiology, 9, 1112-1125.

https://doi.org/10.1111/j.1462-2920.2006.01234.x

Rice, E. W., Baird, R. B., Eaton, A. D., \& Clesceri, L. S. (Eds.). (2012). Standard methods for the examination of water and wastewater $\left(22^{\text {nd }}\right.$ ed.). American Public Health Association, Washington, DC.

Saady, N. M. C. (2013). Homoacetogenesis during hydrogen production by mixed cultures dark fermentation: Unresolved challenge. International Journal of Hydrogen Energy, 38, 13172-13191.

https://doi.org/10.1016/j.ijhydene.2013.07.122

Santos, S. C., Rosa, P. R. F., Sakamoto, I. K., Varesche, M. B. A., \& Silva, E. L. (2014). Continuous thermophilic hydrogen production and microbial community analysis from anaerobic digestion of diluted sugar cane stillage. International Journal of Hydrogen Energy, 39, 9000-9011.

https://doi.org/10.1016/j.ijhydene.2014.03.241

Sikora, A., Błaszczyk, M., Jurkowski, M., \& Zielenkiewicz, U. (2013). Lactic acid bacteria in hydrogen-producing consortia: On purpose or by coincidence? In M. Kongo (Ed.), Lactic acid bacteria $-R \& D$ for food, health and livestock purposes (pp. 487-514). Rijeka, Croatia: Intech.

https://doi.org/10.5772/50364

Tsapekos, P., Kougiasp, G., Treu, L., Campanaro, S., \& Angelidaki, I. (2017). Process performance and comparative metagenomic analysis during co-digestion of manure and lignocellulosic biomass for biogas production. Applying Energy, 185, 126-135.

https://doi.org/10.1016/j.apenergy.2016.10.081

Urbaniec, K., \& Bakker, R. R. (2015). Biomass residues as raw material for dark hydrogen fermentation - A review. International Journal of Hydrogen Energy, 40, 3648-3658. https://doi.org/10.1016/j.ijhydene.2015.01.073

Urbaniec, K., \& Grabarczyk, R. (2014). Hydrogen production from sugar beet molasses - a techno-economic study. Journal Cleaner Production, 65, 324-329. https://doi.org/10.1016/j.jclepro.2013.08.027

Wicher, E., Seifert, K., Zagrodnik, R., Pietrzyk, B., \& Łaniecki, M. (2013). Hydrogen gas production from distillery wastewater by dark fermentation. International Journal of Hydrogen Energy, 38, 7767-7773.

https://doi.org/10.1016/j.ijhydene.2013.04.008 
Xia, A., Cheng, J., \& Murphy, J. D. (2016). Innovation in biological production and upgrading of methane and hydrogen for use as gaseous transport biofuel. Biotechnology Advances, 34, 451-472. https://doi.org/10.1016/j.biotechadv.2015.12.009

Yang, P., Zhang, R., McGarvey, J. A., \& Benemann, J. R. (2007). Biohydrogen production from cheese processing wastewater by anaerobic fermentation using mixed microbial communi- ties. International Journal of Hydrogen Energy, 32, 4761-4771. https://doi.org/10.1016/j.ijhydene.2007.07.038

Zhong, W., Zhang, Z., Luo, Y., Sun, S., Qiao, W., \& Xiao, M. (2011). Effect of biological pretreatments in enhancing corn straw biogas production. Bioresource Technology, 102, 1117711182. https://doi.org/10.1016/j.biortech.2011.09.077

\section{APPENDIX Supplementary material}

Table 1S. Statistical comparison of hydrogen production from batch test with no pretreatment (ANOVA, p value, Tukey's test)

\begin{tabular}{|c|c|c|c|c|c|c|c|c|c|c|c|c|}
\hline Without pretreatment & 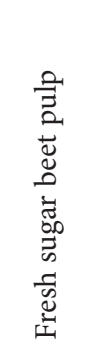 & 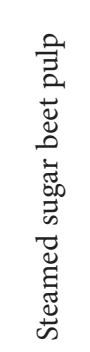 & 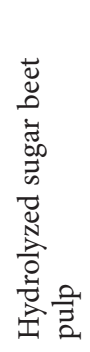 &  &  & 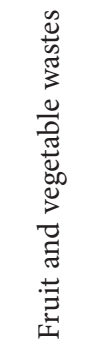 & 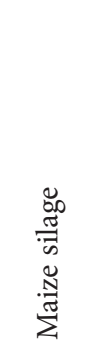 &  & 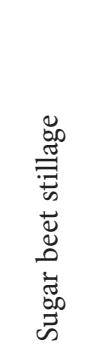 & 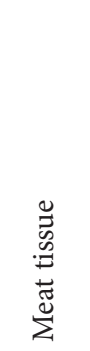 & 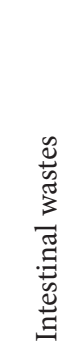 &  \\
\hline Fresh sugar beet pulp & - & - & - & - & - & - & - & - & - & - & - & - \\
\hline Steamed sugar beet pulp & $<0.01$ & - & - & - & - & - & - & - & - & - & - & - \\
\hline Hydrolyzed sugar beet pulp & $<0.01$ & 0.259 & - & - & - & - & - & - & - & - & - & - \\
\hline Sugar beet leaves & $<0,01$ & $<0.01$ & $<0.01$ & - & - & - & - & - & - & - & - & - \\
\hline Kitchen wastes & $<0.01$ & 0.830 & 0.939 & $<0.01$ & - & - & - & - & - & - & - & - \\
\hline Fruit and vegetable wastes & $<0.01$ & 0.198 & 0.175 & $<0.01$ & 0.145 & - & - & - & - & - & - & - \\
\hline Maize silage & $<0.01$ & 0.297 & 0.407 & $<0.01$ & 0.506 & 0.457 & - & - & - & - & - & - \\
\hline Rye stillage & $<0.01$ & $<0.01$ & $<0.01$ & 0.612 & $<0.01$ & $<0.01$ & $<0.01$ & - & - & - & - & - \\
\hline Sugar beet stillage & $<0.01$ & 0.951 & 0.927 & $<0.01$ & 0.884 & 0.215 & 0.351 & $<0.01$ & - & - & - & - \\
\hline Meat tissue & $<0.01$ & $<0.01$ & $<0.01$ & 0.817 & $<0.01$ & $<0.01$ & $<0.01$ & 0.663 & $<0.01$ & - & - & - \\
\hline Intestinal wastes & $<0.01$ & $<0.01$ & $<0.01$ & 0.023 & $<0.01$ & 0.027 & $<0.01$ & 0.047 & $<0.01$ & 0.019 & - & - \\
\hline Post flotation sludge & $<0.01$ & $<0.01$ & $<0.01$ & 0.151 & $<0.01$ & $<0.01$ & $<0.01$ & 0.535 & $<0.01$ & 0.391 & 0.118 & - \\
\hline
\end{tabular}

- p value $<0.01$ (highly significant)

- $\mathrm{p}$ value $<0.05$ (significant)

- $\mathrm{p}$ value $>0.05$ (not significant) 
Table 2S. Statistical comparison of hydrogen production from batch test with $\mathrm{pH}$ adjustment (ANOVA, p value, Tukey's test)

\begin{tabular}{|c|c|c|c|c|c|c|c|c|c|c|c|c|}
\hline $\mathrm{pH}$ adjustment & 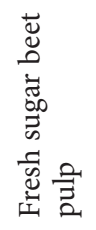 & 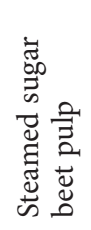 & 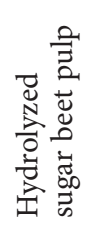 & 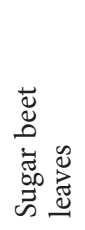 & 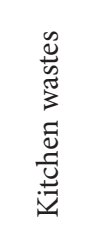 & 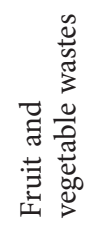 & 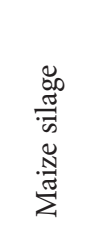 & 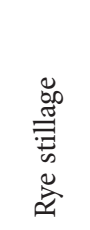 & 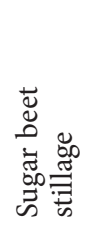 & 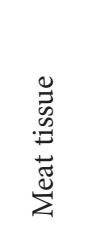 & 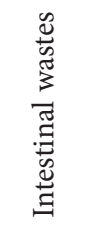 & 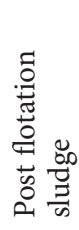 \\
\hline Fresh sugar beet pulp & - & - & - & - & - & - & - & - & - & - & - & - \\
\hline Steamed sugar beet pulp & $<0.01$ & - & - & - & - & - & - & - & - & - & - & - \\
\hline $\begin{array}{l}\text { Hydrolyzed sugar beet } \\
\text { pulp }\end{array}$ & $<0.01$ & $<0.01$ & - & - & - & - & - & - & - & - & - & - \\
\hline Sugar beet leaves & $<0.01$ & $<0.01$ & $<0.01$ & - & - & - & - & - & - & - & - & - \\
\hline Kitchen wastes & $<0.01$ & $<0.01$ & $<0.01$ & $<0.01$ & - & - & - & - & - & - & - & - \\
\hline $\begin{array}{l}\text { Fruit and vegetable } \\
\text { wastes }\end{array}$ & $<0.01$ & $<0.01$ & $<0.01$ & $<0.01$ & $<0.01$ & - & - & - & - & - & - & - \\
\hline Maize silage & $<0.01$ & $<0.01$ & 0.865 & $<0.01$ & $<0.01$ & 0.023 & - & - & - & - & - & - \\
\hline Rye stillage & $<0.01$ & $<0.01$ & $<0.01$ & 0.051 & 0.169 & $<0.01$ & $<0.01$ & - & - & - & - & - \\
\hline Sugar beet stillage & $<0.01$ & $<0.01$ & $<0.01$ & $<0.01$ & $<0.01$ & $<0.01$ & $<0.01$ & $<0.01$ & - & - & - & - \\
\hline Meat tissue & 0.146 & $<0.01$ & $<0.01$ & 0.035 & 0.025 & $<0.01$ & $<0.01$ & $<0.01$ & $<0.01$ & - & - & - \\
\hline Intestinal wastes & $<0.01$ & $<0.01$ & $<0.01$ & $<0.01$ & $<0.01$ & $<0.01$ & $<0.01$ & $<0.01$ & $<0.01$ & $<0.01$ & - & - \\
\hline Post flotation sludge & $<0.01$ & $<0.01$ & $<0.01$ & $<0.01$ & $<0.01$ & $<0.01$ & $<0.01$ & $<0.01$ & $<0.01$ & $<0.01$ & 0.206 & - \\
\hline
\end{tabular}

- $\mathrm{p}$ value $<0.01$ (highly significant)

$\square$ - p value $<0.05$ (significant)

- $\mathrm{p}$ value $>0.05$ (not significant)

Table 3S. Statistical comparison of hydrogen production from batch test with thermal treatment (ANOVA, p value, Tukey's test)

\begin{tabular}{|c|c|c|c|c|c|c|c|c|c|c|c|c|}
\hline Thermal treatment & 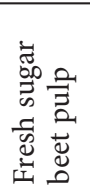 & 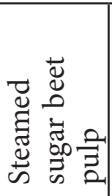 & 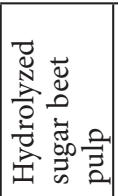 & 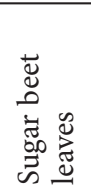 & 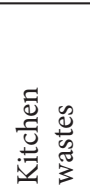 &  & 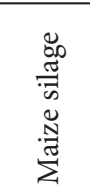 & 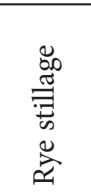 &  & 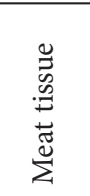 & 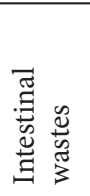 &  \\
\hline Fresh sugar beet pulp & - & - & - & - & - & - & - & - & - & - & - & - \\
\hline $\begin{array}{l}\text { Steamed sugar beet } \\
\text { pulp }\end{array}$ & $<0.01$ & - & - & - & - & - & - & - & - & - & - & - \\
\hline $\begin{array}{l}\text { Hydrolyzed sugar beet } \\
\text { pulp }\end{array}$ & $<0.01$ & $<0.01$ & - & - & - & - & - & - & - & - & - & - \\
\hline Sugar beet leaves & $<0.01$ & $<0.01$ & 0 & - & - & - & - & - & - & - & - & - \\
\hline Kitchen wastes & $<0.01$ & $<0.01$ & $<0.01$ & $<0.01$ & - & - & - & - & - & - & - & - \\
\hline $\begin{array}{l}\text { Fruit and vegetable } \\
\text { wastes }\end{array}$ & $<0.01$ & 0.645 & $<0.01$ & $<0.01$ & $<0.01$ & - & - & - & - & - & - & - \\
\hline Maize silage & $<0.01$ & $<0.01$ & $<0.01$ & $<0.01$ & $<0.01$ & $<0.01$ & - & - & - & - & - & - \\
\hline Rye stillage & 0.016 & $<0.01$ & $<0.01$ & $<0.01$ & $<0.01$ & $<0.01$ & $<0.01$ & - & - & - & - & - \\
\hline Sugar beet stillage & $<0.01$ & $<0.01$ & $<0.01$ & $<0.01$ & $<0.01$ & $<0.01$ & $<0.01$ & $<0.01$ & - & - & - & - \\
\hline Meat tissue & $<0.01$ & $<0.01$ & $<0.01$ & $<0.01$ & $<0.01$ & $<0.01$ & $<0.01$ & $<0.01$ & $<0.01$ & - & - & - \\
\hline Intestinal wastes & 0.595 & $<0.01$ & $<0.01$ & $<0.01$ & $<0.01$ & $<0.01$ & $<0.01$ & $<0.01$ & 0.143 & $<0.01$ & - & - \\
\hline Post flotation sludge & 0.983 & $<0.01$ & $<0.01$ & $<0.01$ & $<0.01$ & $<0.01$ & $<0.01$ & $<0.01$ & 0.025 & $<0.01$ & 0.435 & - \\
\hline
\end{tabular}

$\square$ - p value $<0.01$ (highly significant)

$\square-\mathrm{p}$ value $<0.05$ (significant)

$\square$ - p value $>0.05$ (not significant) 
Table 4S. Statistical comparison of hydrogen production from batch test with thermal treatment and $\mathrm{pH}$ adjustment (ANOVA, p value, Tukey's test)

\begin{tabular}{|c|c|c|c|c|c|c|c|c|c|c|c|c|}
\hline $\begin{array}{l}\mathrm{pH} \text { adjustment and } \\
\text { thermal treatment }\end{array}$ & 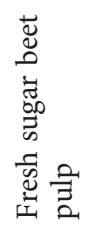 &  & 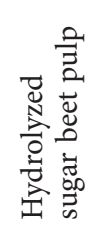 & 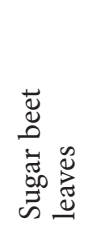 &  &  &  &  & 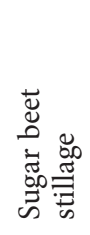 & 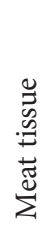 & 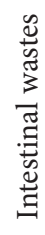 & 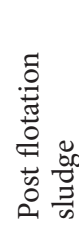 \\
\hline Fresh sugar beet pulp & - & - & - & - & - & - & - & - & - & - & - & - \\
\hline $\begin{array}{l}\text { Steamed sugar beet } \\
\text { pulp }\end{array}$ & $<0.01$ & - & - & - & - & - & - & - & - & - & - & - \\
\hline $\begin{array}{l}\text { Hydrolyzed sugar beet } \\
\text { pulp }\end{array}$ & $<0.01$ & $<0.01$ & - & - & - & - & - & - & - & - & - & - \\
\hline Sugar beet leaves & 0.053 & $<0.01$ & $<0.01$ & - & - & - & - & - & - & - & - & - \\
\hline Kitchen wastes & $<0.01$ & $<0.01$ & $<0.01$ & $<0.01$ & - & - & - & - & - & - & - & - \\
\hline $\begin{array}{l}\text { Fruit and vegetable } \\
\text { wastes }\end{array}$ & $<0.01$ & $<0.01$ & $<0.01$ & $<0.01$ & $<0.01$ & - & - & - & - & - & - & - \\
\hline Maize silage & $<0.01$ & $<0.01$ & $<0.01$ & $<0.01$ & $<0.01$ & $<0.01$ & - & - & - & - & - & - \\
\hline Rye stillage & $<0.01$ & $<0.01$ & $<0.01$ & $<0.01$ & $<0.01$ & $<0.01$ & 0.435 & - & - & - & - & - \\
\hline Sugar beet stillage & $<0.01$ & $<0.01$ & $<0.01$ & $<0.01$ & 0.016 & $<0.01$ & $<0.01$ & $<0.01$ & - & - & - & - \\
\hline Meat tissue & $<0.01$ & $<0.01$ & $<0.01$ & $<0.01$ & $<0.01$ & $<0.01$ & $<0.01$ & $<0.01$ & $<0.01$ & - & - & - \\
\hline Intestinal wastes & $<0.01$ & $<0.01$ & $<0.01$ & $<0.01$ & $<0.01$ & $<0.01$ & $<0.01$ & $<0.01$ & $<0.01$ & - & - & - \\
\hline Post flotation sludge & $<0.01$ & $<0.01$ & $<0.01$ & $<0.01$ & $<0.01$ & $<0.01$ & $<0.01$ & $<0.01$ & $<0.01$ & - & - & - \\
\hline
\end{tabular}

- $\mathrm{p}$ value $<0.01$ (highly significant)

- p value $<0.05$ (significant)

- $\mathrm{p}$ value $>0.05$ (not significant) 